\title{
Dungaw: Re-imagined Religious Expression in Response to the COVID-19 Pandemic
}

\section{Fides A. del Castillo ${ }^{1}$ (D) . Clarence Darro del Castillo ${ }^{2} \cdot$ Jeff Clyde Corpuz $^{1}$}

Accepted: 15 April 2021 / Published online: 27 April 2021

(C) The Author(s), under exclusive licence to Springer Science+Business Media, LLC, part of Springer Nature 2021

\begin{abstract}
Expressions of religious piety have been practiced in the Catholic Church as a response to plagues and pandemics. The faithful seek comfort in prayer and appeal to God and the saints for mercy and protection from illness and loss of life. In the Philippines, the veneration of sacred images and placing them outside the window of a house or a church is a religious expression known as "dungaw" (to look out). This paper discusses "dungaw" as a faith-response of Filipino Catholics during the COVID-19 pandemic. The study is an empirical phenomenology that consists of a literary review and interviews. This paper analyzed the significance of the religious expression "dungaw." Four areas of inquiry were identified: (1) Views on the COVID-19 pandemic, (2) "Dungaw" and prayer life during the pandemic, (3) "Dungaw" as a religious expression, and (4) "Dungaw" and communal life. Results showed that Filipino Catholics utilized religion as a coping resource during turbulent times. Filipino Catholics also embodied traditional values to help repair the frayed social fabric during COVID-19.
\end{abstract}

Keywords Religious coping $\cdot$ Culture $\cdot$ Spirituality $\cdot$ Health $\cdot$ Religion $\cdot$ Popular devotions $\cdot$ Sacred images $\cdot$ COVID-19

Fides A. del Castillo

fides.delcastillo@dlsu.edu.ph

Clarence Darro del Castillo

cdbdelcastillo@gmail.com

Jeff Clyde Corpuz

jeff.corpuz@dlsu.edu.ph

1 Department of Theology and Religious Education, College of Liberal Arts, De La Salle University, 2401 Taft Avenue, Malate, 0922 Manila, Philippines

2 Lumina Foundation for Integral Human Development, Inc., 4027 Calamba, Laguna, Philippines 


\section{Introduction}

Religion, conceptualized as "beliefs, practices, and rituals related to the transcendent or ultimate truth/reality is a multidimensional construct that may be held or practiced in private or public settings" (Koenig, 2012, pp. 2-3). As a system of significance that is grounded in a person's belief in the sacred and realized within a broader religious context (Talik, 2013, p. 146), religion is significant to many people, and many fascinating behaviors are performed in its name (Hood et al., 2009, p. 1). The religious commitment of people and the influence of religion on a person's subjective experience and behavior are demonstrated in the various dimensions of religion such as intellect, ideology, public practice, private practice, and religious experiences (Huber \& Huber, 2012). Moreover, numerous empirical studies show that for many people, religion is an integral part of human existence (Koenig, 2012). It can play a crucial role in people's search for meaning and a sense of life (Nakonz \& Shik, 2009). Also, some religious people find comfort in the abiding presence of the divine or sacred during difficult moments (Rilveria, 2018). Moreover, many religious people ask for help from the transcendent or divine (Rilveria, 2018) and collaborate with God in solving major stressors (del Castillo \& Alino, 2020; Pargament et al., 2000).

The coronavirus disease 2019 (COVID-19), which infected more than 62 million people and claimed over 1 million lives, is a threat to global health (Fauci et al., 2020; World Health Organization [WHO], 2020a). For many religious people, the COVID-19 pandemic has also become a test of faith (Baker et al., 2020; Singh, 2020). To mitigate the spread of the novel coronavirus disease, the World Health Organization (2020b) advised people to practice social distancing, wear face masks, avoid spaces that are closed, crowded, or involve close contact, and observe good hygiene. While social distancing may have prevented people from COVID-19 infection, the public health measure also significantly reduced the available supply of religion in the form it was expected (Baker et al., 2020). Catholic priests who succumbed to COVID-19 exacerbated the need for religious ministers and made some people find alternative spiritual measures (Bramstedt, 2020). The imposition of community quarantine led to the cancelation of numerous religious services, pilgrimages, and religious festivals (Dein et al., 2020). The COVID-19 pandemic also forced the privatization of religious practices, wherein religious services and rituals were consumed via asynchronous communication (Baker et al., 2020). Reeling from the impact of the COVID-19 pandemic and the specter of uncertainty, many religious people realized that "the only certainty is their religious faith, which is a rock that they are now needing to hold onto" (Hart \& Koenig, 2020, p. 1141).

Poverty, limited health care resources, and densely populated slums make the Philippines susceptible to a viral pandemic. Out of the 106 million Filipinos, around 431,630 have been infected with COVID-19 resulting in 8392 fatalities (Center for Strategic \& International Studies, 2020). The public health emergency compelled the Philippine government to implement community quarantine procedures to reduce the doubling time of COVID-19 infections, prevent hospitals 
from being overwhelmed, create emergency facilities for sick and convalescing people, and reduce deaths (Vallejo \& Ong, 2020). The COVID-19 pandemic strained the social fabric, threatened the health care capacity of the country, and put the faith of numerous Filipino Catholics to the test. Since many Filipino Catholics approach God with other people when they participate in Eucharistic celebrations, processions, and large trans-parochial crowds (Alejo, 2004), they felt anxious and isolated when their connection with spiritual leaders and church peers was curtailed (Buenaventura et al., 2020).

Interestingly, the COVID-19 pandemic did not only usher a collective memory of traumatic events among religious people. It also provided many Filipino Catholics with a generational consciousness to facilitate a coordinated response and practice social solidarity. There are Catholic religious congregations that served the spiritual needs of the people through online-based Church masses (Pabillo, 2020; Rosales, 2021). Moreover, the Catholic Church opened its doors to the homeless population, provided protective equipment to health workers, initiated feeding programs, and extended holistic care to the people.

\section{Objectives of the Study}

Dungaw is a Filipino term that means "to look out." It is a lived religious experience, wherein some Filipino Catholics placed iconographical representations of Jesus Christ, the Blessed Virgin Mary, or Catholic saints near the window or door of a house. Dungaw, an act of popular religiosity, embodies the Catholic Church's teaching on sacred signs that refer to Jesus Christ (Congregation for Divine Worship \& the Discipline of the Sacraments, 2001).

This paper examines the religious expression dungaw and its role as a coping resource for selected Filipino Catholics during the COVID-19 pandemic. To the best of our knowledge, the contribution of dungaw to individuals' positive psychological state has not been dealt with in-depth. The researchers aim to verify if the "belief in the sacred or divine and the consequent spiritual experience leads to positive psychological states such as peace, hope, and joy" (del Castillo, 2020). Moreover, the researchers aim to contribute to the literature on the interaction of Catholic lived experiences, Filipino culture, and religious coping.

Within the empirical phenomenology framework, the researchers aim to answer the following: (1) What are the views of selected Filipino Catholics regarding the COVID19 pandemic? (2) What is the relationship between dungaw and the private practice dimension of religion among selected Filipino Catholics? (3) Why is dungaw a genuine form of Filipino Catholic popular piety? (4) What are the implications of dungaw to the communal life of selected Filipino Catholics? 


\section{Review of Related Literature}

There is a considerable amount of literature on Filipino Catholic popular religiosity. For reasons of space, this section focuses on religion as a coping resource to deal with difficult circumstances, the importance of Catholic sacred images and belief in their power to protect and heal, and the re-imagination of religious expressions as a response to the COVID-19 pandemic.

\section{Religion as a Coping Resource}

Many empirical studies revealed that religion could help a person handle daily life problems (Koenig, 2012; Pargament et al., 1988). However, Hood et al. (2009) assert that "the real test of faith comes when common hassles are supplemented by the major trials of human existence" (p. 472). Some of these ordeals are the danger of death, the death of one's children, scorn of the one who suffers, loneliness, and abandonment (John Paul II, 1984). Since religion can foster positive psychological states such as joy or hope, it can help buffer stress and protect against adverse psychological conditions such as fear, sadness, or anger (Hood et al., 2009). Moreover, a person's relationship with the divine or sacred can serve as a coping resource in dealing not just with minor stressors, but also during major trials in life (Belavich, 1995; del Castillo \& Alino, 2020; Pargament et al., 2011). Thus, religious coping is demonstrated by persons who exert "effort to understand and deal with life stressors in ways related to the sacred" (Pargament et al., 2011, p. 52).

In a predominantly Catholic country like the Philippines, the salience of religion during a global health crisis is manifested by numerous Filipinos who declared that "faith is very important" in the fight against COVID-19 (Patinio, 2020). The importance of religion to many Filipinos is also demonstrated by their participation in religious services every week (Social Weather Stations, 2019, p. 1). These align with the findings of Del Castillo et al. (2020) that there are a significant number of religiously committed Filipinos. Also, many Filipino Catholics utilize religion as a coping resource to deal with the major challenges in life (del Castillo \& Alino, 2020).

\section{Catholic Religious Icons: Reminders of God's Presence and Saving Help}

The Catholic Church teaches that sacred images "facilitate supplication and prompts the believers to give glory to God for the marvels done by his grace" (Congregation for Divine Worship \& the Discipline of the Sacraments, 2001, para. 240). Hence, religious images serve as devotional aids that remind Catholics of the sacred personages whom they address in prayers (Abogado, 2006). The period from the fifth century onwards marked the formative stage in the growth of cult and veneration of Catholic religious icons, most especially during a plague (Cameron, 2016). Such religious piety has been documented during the Justinianic Plague in AD 541-544 (Meier, 2016), and the Bubonic Plague (Black Death), wherein "the predominant response of Catholics was to seek solace in prayers and direct their religious appeals 
to God and saints known for their mercy or power" (Aberth, 2005). As a religious response to the COVID-19 pandemic, Pope Francis led a prayer service at the Vatican, beseeching God to protect the people from the virulent disease. With the "Miraculous Crucifix" prominently displayed on the sagrato of St. Peter's Basilica, the Roman Pontiff prayed and gave his papal address and apostolic blessing to the world (Vizzi, 2020).

The veneration of sacred images to express gratitude to God and implore the help of the divine during difficult moments is also demonstrated by many Filipino Catholics in the Philippines. Although the Philippine Constitution specifies that people have the freedom to choose and practice their religion, around $80 \%$ of the 101 million Filipinos are Roman Catholics (Philippine Statistics Authority [PSA], 2017). The Catholic religion was introduced to the country at the onset of the Spanish conquest in 1521 and became embedded into Filipino culture (del Castillo, 2015; Goh, 2005). John Paul II (1981) described Filipino Catholicism as the product of "the rich geographical and human diversity, various cultural traditions, people's spirit of joy and sharing, and missionary efforts" (para. 2). Noteworthy examples of the close link between Catholic ideology and the public practice dimension of religion among many Filipinos are their attendance to Eucharistic celebrations and active participation in religious feasts. For a significant number of older Filipino Catholics, faith serves as a source of strength and protective buffer from stress and suffering. As such, they go to Mass regularly (Buenaventura et al., 2020).

The salience of religion to a significant number of Filipino Catholics is also manifested in popular forms of religiosity wherein religious icons serve as the object of devotion. An example is a devotion to Nuestro Padre Jesus Nazareno de Quiapo in Metro Manila (a city in the National Capital Region). Popularly known as Señor Nazareno or the Black Nazarene, the 17th-century life-sized image of a dark-colored kneeling Jesus Christ has a huge number of devotees. Every Friday, hundreds of Filipino Catholics attend the Eucharistic celebrations at the Minor Basilica of the Black Nazarene. After the Mass, the devotees "wipe the image of the Black Nazarene with their handkerchief and put the cloth to an ailing part of their body as a sign of faith and supplication for a physical cure" (Deguma et al., 2019, p.4).

Moreover, numerous devotees demonstrate their religious zeal to Señor Nazareno in the traslación, a barefoot procession along the streets that lasts for almost $20 \mathrm{~h}$, an integral part of the Black Nazarene's feast day celebrations. In the traslación, it is common to see some devotees pushing each other to reach and touch the Black Nazarene. Despite some people getting injured, the spiritual fervor of the devotees remains (Espiritu, 2016).

Another unique Catholic religious festival is held in the Bicol region (some $400 \mathrm{~km}$ southeast of Manila), wherein numerous Filipino Catholics venerate the images of the Blessed Virgin Mary and the Face of Jesus Christ. Known as the Peñafrancia Festival, devotion to the Lady of Peñafrancia began in 1712 when a sick seminarian named Miguel Robles de Covarrubias attributed his healing to the image. In 1882, a cholera epidemic infected the city. However, people claimed that those who prayed to the image of Divino Rostro (the face of Christ) were spared from illness and death. The Peñafrancia Festival also includes a traslación, wherein the Lady of Peñafrancia and the Divino Rostro are paraded from Basilica Minore 
to the Metropolitan Cathedral. The highlight of the festival is the fluvial procession, wherein the image of the Blessed Virgin Mary is transferred from the streets onto a pontoon-like boat. Accompanied by a multitude of devotees on smaller boats, the Lady of Peñafrancia traverses the river until it reaches the Cathedral (Peterson, 2020).

In Cebu (an island in the Visayas region), a statue of the Christ child believed to be the same image brought by Ferdinand Magellan in 1521 (del Castillo, 2015) serves as the object of devotion for numerous Filipinos. Every day, hundreds of devotees visit the Basilica Minore del Santo Niño de Cebu to queue and wait for hours just to touch the image of the Santo Niño and pray for a cure from sickness and request for other blessings (Bautista, 2010). The feast of the Santo Niño is celebrated during the Sinulog festival, wherein numerous people attend the liturgical celebrations and then participate in dancing the sug (a native term referring to the movement of a river current). Accompanied by drum beats, the dancers also carry an image of the Santo Niño while performing on the streets (Ortiz et al., 2017). Through music and sug, the individual body rhythms of many devotees are synchronized, which culminates in a dance and worship spectacle.

\section{Dungaw: A Catholic Religious Expression Re-imagined}

To cope with anxiety and fear and gain a sense of control over the uncertainties brought by the COVID-19 pandemic, many Filipino Catholics have turned to their religion and faith. However, due to community quarantine restrictions, the public religious practices of Catholics had to be re-imagined. Since Catholic Churches were closed, many Filipino Catholics opted to pray the rosary at home, viewed online Masses (Pabillo, 2020; Rosales, 2021), and devoted more time to personal prayers. Also, there are Filipino Catholics who practiced dungaw as a religious response to the health crisis.

The Catholic religious expression dungaw involves placing iconographical representations of Jesus Christ, the Blessed Virgin Mary, or Catholic saints at the window or door of a house at 6 o'clock in the evening. The religious images are positioned in such a way that they are looking outside or facing the street. Some Filipino Catholics place the sacred images on a la mesita (small table) and illumine the makeshift altar with candles. Integral to the practice of dungaw is the gathering of the family to sing a liturgical song and then praying the Holy Rosary as well as the Oratio Imperata (Obligatory Prayer). The Oratio Imperata implores God's protection, blesses health workers, and calls upon the intercession of the Blessed Virgin Mary and the Catholic saints. Dungaw draws inspiration from Filipino Catholic devotions to religious icons and feasts that celebrate the belief in the healing power of God, the protection of the Blessed Virgin Mary, and the intercession of Catholic saints (Pabillo, 2020). Hence, those who practice dungaw hope that God will protect them from the virulent disease, console the suffering, cure the sick, foster hope during the health crisis, and miraculously end the COVID-19 pandemic.

As a religious expression, "dungaw" may seem unsophisticated, superstitious, and emotional. However, it is an important form of popular piety during the 
COVID-19 pandemic when public practices of religion are restricted. Also, the Catholic Church proclaims that "authentic expressions of popular piety are not at odds with the centrality of the Sacred Liturgy." Instead, in promoting the faith of the people who regard popular piety as a natural religious expression, they predispose the people to celebrate the Sacred Mysteries (Congregation for Divine Worship \& the Discipline of the Sacraments, 2001, para. 4).

\section{Methodology}

This study employed empirical phenomenology to discover the significance of dungaw and its connection to the meaning structure of selected Filipino Catholics during the COVID-19 pandemic. The term phenomenology emerged as early as 1765 in the writings of Emmanuel Kant. However, only with Hegel was that a well-defined technical meaning was constructed (Kockelmans, 1967). Hegel referred to phenomenology as knowledge as it appears to consciousness. It is the science of describing what one perceives and the process that leads to the unfolding of phenomenal experiences toward the absolute knowledge of the Absolute (Kockelmans, 1967, p. 24). This is supported by Aspers (2009) by pointing that empirical phenomenology is an approach to define the focus of phenomenology "that which appears." It means that the participants' perspective is central in the analysis, and phenomenology comes from the assumption that a scientific explanation is grounded in the meaning structure of those being studied. Hence, empirical phenomenology recognizes the significant role of theory in research and the role of the participants' perspectives.

Table 1 Demographics of the respondents

\begin{tabular}{lcr}
\hline Variables & Total & $\%$ \\
\cline { 2 - 3 } & $n$ & \\
\hline Gender & & 54 \\
Male & 12 & 46 \\
Female & 10 & 100 \\
Total & 22 & \\
Location & & 70 \\
Rural & 15 & 30 \\
Urban & $7 \%$ & \\
Total & 22 & 100 \\
Religion & & 100 \\
Catholic & 22 & \\
Other religion & 0 & \\
Total & 22 & \\
\hline
\end{tabular}




\section{Demographics}

For phenomenological studies, Creswell (1998) recommends 5-25 participants. Hence, this study has a good sampling size. Table 1 shows that there are twenty-two (22) Filipino Catholics participants whose age ranges from 22 to 40 years of age. There are ten (10) females and twelve (12) males. All respondents have practiced or experienced dungaw. They have experienced placing either an image of Mary or the saints on the window or outside their homes. Seventy percent $(70 \%)$ of the respondents live in rural areas, and thirty percent (30\%) live in urban settings. The study was conducted following the guidelines of the ethical principles for research. Informed consent was given, and utmost confidentiality was observed in the conduct of this research.

\section{Procedure and Instrument}

Informed by the research theories on lived religious experiences and grounded on the perspectives of people who had knowledge or practiced dungaw, the researchers created open-ended survey questions to unpack the salience of religion and its utility as a coping resource for a group of Filipino Catholics. The survey questions solicited information regarding (1) The perspectives of selected Filipino Catholics on the COVID-19 pandemic (2) The relationship between dungaw and Catholic prayers according to a group of Filipino Catholics (3) The practice of dungaw as a genuine form of religious piety as demonstrated by selected Filipino Catholics and (4) The salience of dungaw to the communal life of some Filipino Catholics. Data were collected using an online survey where the researchers determined the subjects purposively to answer the research questions.

\section{Data Analysis}

The information provided by the respondents (first-order construction) was analyzed and categorized by the researchers into themes (second-order constructions). The researchers then synthesized the information and made conclusions. Table 2 summarizes the empirical phenomenological process. Seven steps were utilized by the researchers. These steps were done by maintaining a scientific attitude to present a solid grasp of the meaning of dungaw and its connection to the meaning structure of the selected Filipino Catholics.

\section{Results and Discussion}

This section shows the results of the analyzed survey. Table 3 indicates that there are respondents who consider the COVID-19 pandemic as a major trial in life. The first-order constructs "hunger," "death," "human limitations and powerlessness," and "ruined jobs, relationships, and opportunities" indicate a disruption in 
Table 2 Empirical phenomenological approach

\begin{tabular}{ll}
\hline Steps & Empirical phenomenological approaches \\
\hline First & $\begin{array}{c}\text { The research questions were defined. Within the framework of empirical phenomenology, the } \\
\text { researchers aimed to answer the research questions posed } \\
\text { The researchers conducted a preliminary study about religious practice. In this process, gath- } \\
\text { ering related literature, informal interview, and participant observations were done to gain } \\
\text { an overview of the research } \\
\text { Choosing the theories for the study. Theories on religious expressions and religious coping } \\
\text { during the time of pandemic were identified to ground the perspectives of the participants of } \\
\text { the study. These were also used as a scheme of reference } \\
\text { Defining the first-order constructs. It is where the researchers analyze the participants' per- } \\
\text { spectives to reveal their meaning. The first-order constructs gathered information about what } \\
\text { the participants mean from their religious experiences and how these experiences relate } \\
\text { to each other. The researchers analyzed the data by organizing the meanings, patterns, and } \\
\text { themes based on their answers. It is grounded in the understanding of the participants, and } \\
\text { the phenomena studied } \\
\text { Developing the second-order constructs. This step consists of generating the central theme } \\
\text { from the first-order constructs. This is understanding the deeper meaning of the first-order } \\
\text { constructs by exploring the patterns and connecting them with existing theories }\end{array}$ \\
Fourth & $\begin{array}{l}\text { The researchers evaluated the first-order constructs and related them to the theoretical notions } \\
\text { of the theories on religious expressions } \\
\text { The last steps are checking for unintended effects and relating the evidence to the scientific } \\
\text { literature and empirical study field. The researchers then synthesized the information and } \\
\text { made conclusions }\end{array}$ \\
Fifth &
\end{tabular}

their usual way of life. Moreover, the constructs "fear," "anxiety," "uncertainty," and "sadness" signify a negative psychological state. Despite the distressing situation, some respondents saw a silver lining. Some believed that the community quarantine provided them with the opportunity to be with loved ones. This reflects the familycenteredness of many Filipinos and the human need for belonging, stability, and security (Catholic Church Bishops' Conference of the Philippines, 1997, para. 34). Utilizing the Catholic religion as a coping resource, some respondents believed that "God is working and He is in control" during the COVID-19 pandemic and that during difficult moments "a person is living a new life in Christ." These cognitive strategies show that there are Filipino Catholics who evaluate a major life stressor by collaborating with God. Also, despite the limitations imposed by the Philippine government on the movement of people, some respondents continued to trust the government authorities and deemed essential workers or "authorized persons outside of residence" as modern-day heroes.

Table 4 shows the relationship between dungaw and the private practice dimension of religion among selected Filipino Catholics. Since dungaw includes praying the rosary and the Oratio Imperata as well as personal requests, the respondents devoted themselves to God in the private space. A prayer which may refer to "thoughts, attitudes, and actions designed to express or experience a connection to the sacred" (McCullough \& Larson, 1999, p. 86), was described by some of the respondents using the first-order constructs "more active," "consistent," "passionate," "deeper," "sincere and selfless," and "frequent." These indicate that there are 


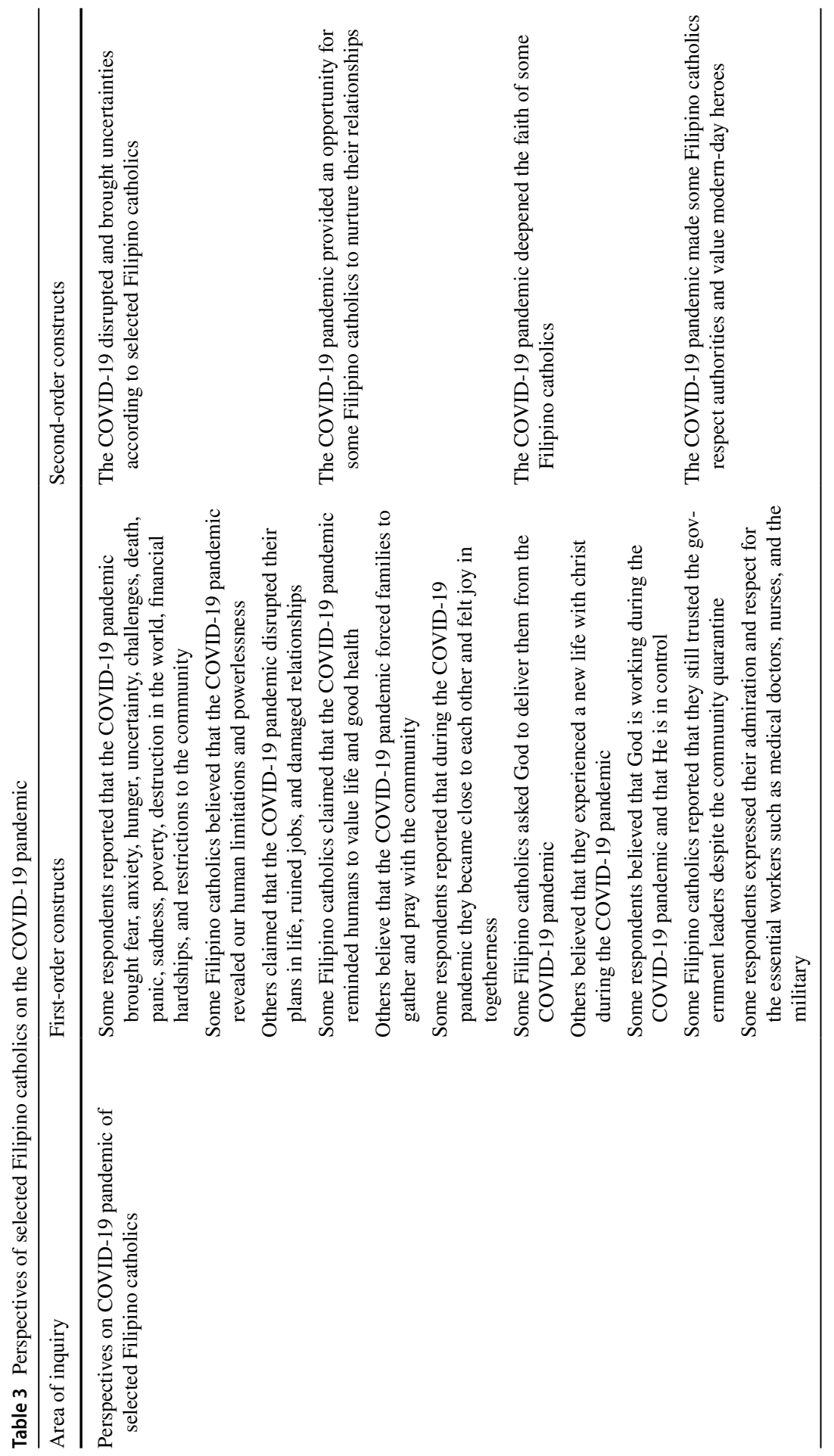




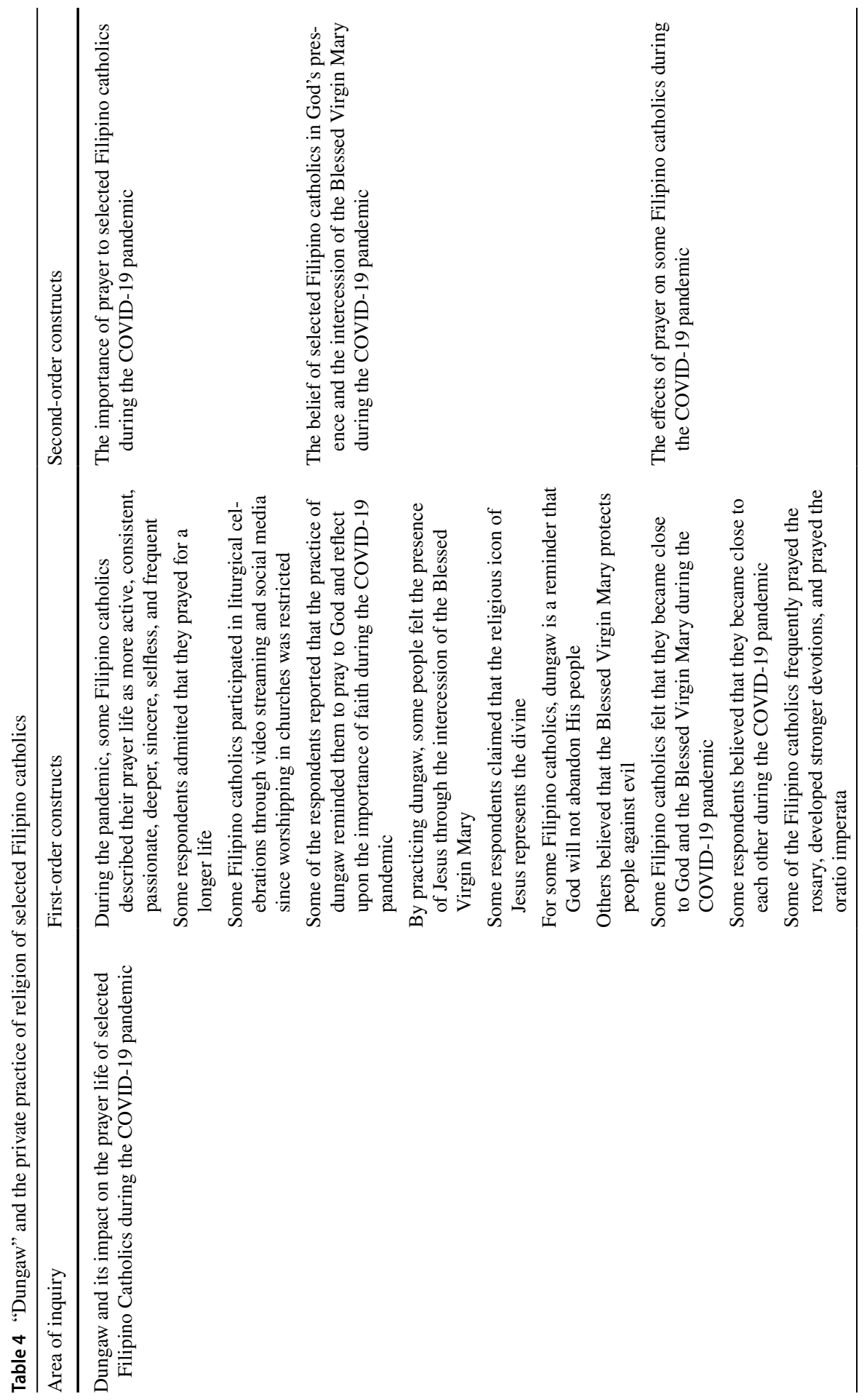




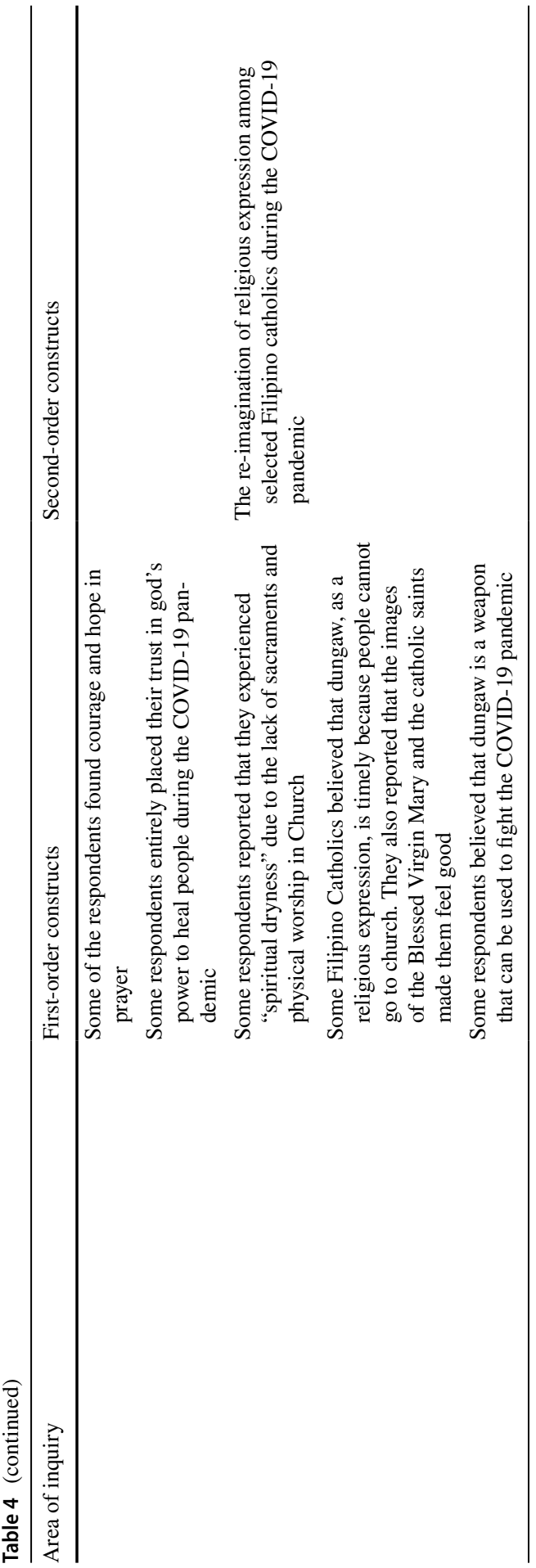


Filipino Catholics who valued and benefitted from prayer during the COVID-19 pandemic. Revealing their fear of getting infected with COVID-19 and the possibility of death, some respondents mentioned that they "prayed for a longer life". This aligns with the assertion of Parks-Stamm et al. (2019) that "prayer buffers individuals from negative stressors and facilitates emotional adjustment" (p. 1).

Some respondents mentioned that dungaw and praying helped them to "feel the presence of Jesus through the intercession of Mary" and were reminded of God's protection. This brings to mind the assertion of James (1917) that prayer is "the very movement of the soul which puts itself in a personal relation of contact with a mysterious power" (p. 350). Through the sacred images and prayer, some Filipino Catholics invoked God's presence during the COVID-19 pandemic.

Also, some informants revealed that they became close to their family members through dungaw. This affirms the positive influence of religion on physical health through the social pathway. Koenig (2012) asserts, "if religion boosts supportive social interactions and increases community trust and involvement, then it should ultimately influence physical health as well" (p. 12).

Among selected Filipino Catholics, dungaw and Catholic prayers facilitated the deepening of their faith, improved their interpersonal relationships, gave them courage, and made them look forward to better days. This aligns with the observation of Koenig (2012) that people pray to God because they have powerful cognitions of a transcendent being who can positively change a dire situation. Moreover, people who have feelings of God-mediated control become optimistic and less depressed (Jeppsen et al., 2015).

There are some Filipino Catholics who shared that they opted to pray through video streaming and social media. However, they struggled with "spiritual dryness" due to the lack of participation in liturgical celebrations. Others affirmed the importance of dungaw and prayers in the fight against COVID-19. Since many religious Filipino Catholics cannot go to Church, they found consolation in praying with the image of the Blessed Virgin Mary and the Catholic saints. These first-order constructs show the necessity of prayer. Prayer is important because it helps a religious person feel interpersonally close to God, especially when he/she needs support in difficult times (Jeppsen et al., 2015).

Table 5 shows that the practice of dungaw is rooted in Filipino Catholic culture. Some of the respondents claimed that the practice of dungaw is inspired by the religious procession of Catholic religious icons. Invoking the power of God and the intercession of the Blessed Virgin Mary and the Catholic saints, selected Filipino Catholics brought sacred images to the window or door at 6:00 PM (which is usually the time for the Angelus prayer), lighted candles, and prayed the Holy Rosary and Oratio Imperata.

Interestingly, some Filipino Catholics claimed that the practice of dungaw was taught to them by their elders. This seems to indicate that the practice of dungaw was learned through socially mediated reinforcement. In the Philippines where the majority of adults are Catholics, parents and elders are powerful models of religious beliefs and behavior. As such, children imitate them after receiving reinforcements like verbal praise and social acceptance (Strand, 2009). 


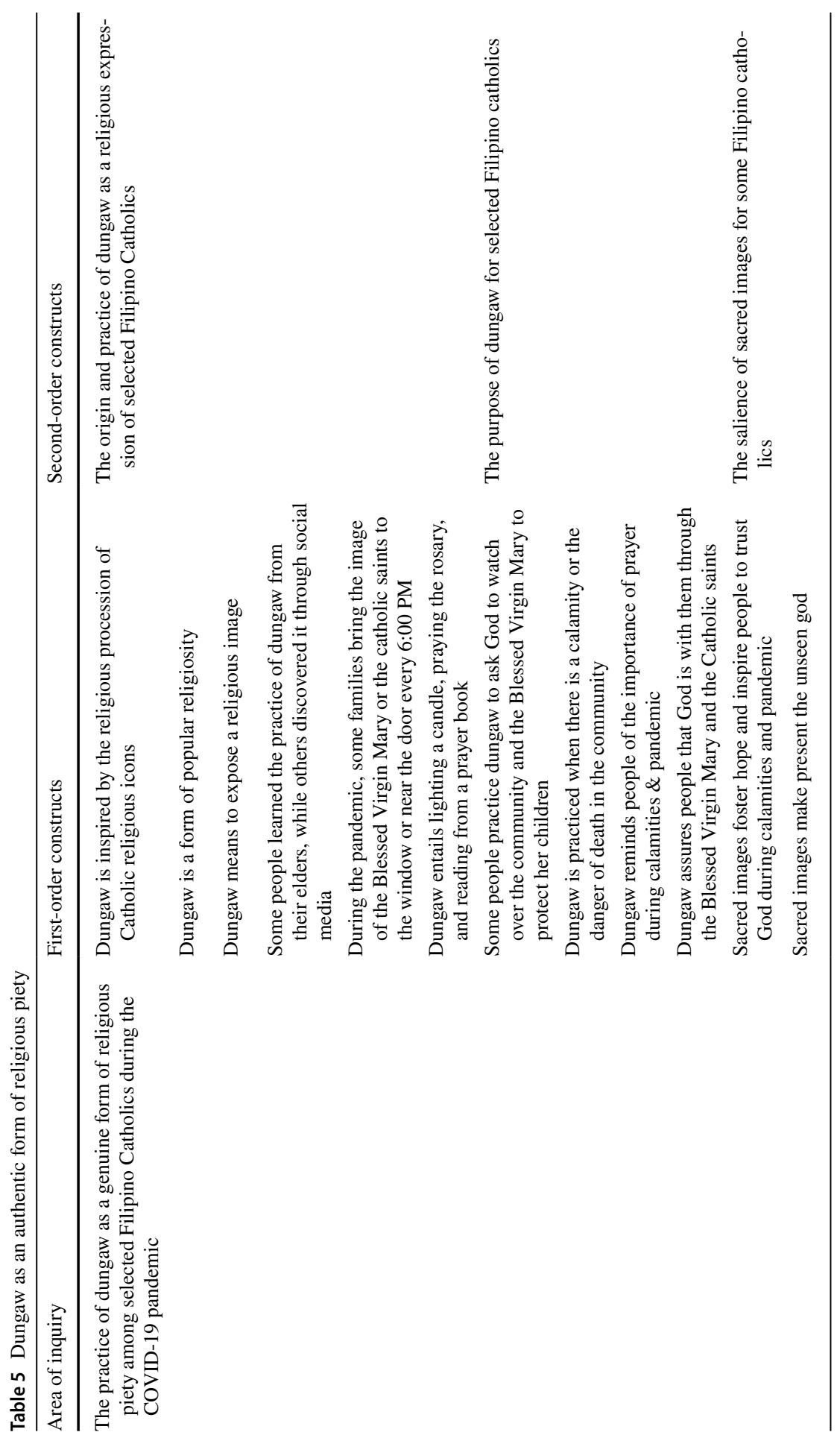




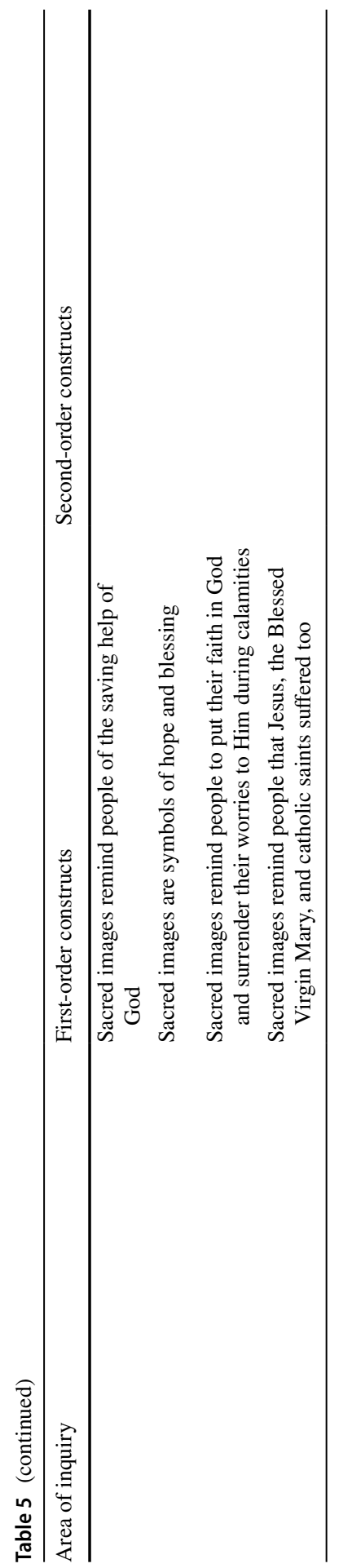


There are some Filipino Catholics who claimed that they felt God's presence through dungaw. The sacred images reminded them that the Blessed Virgin Mary and the Catholic saints watch over them and protect them from harm. For some of the respondents, the sacred images made present the unseen God. This belief fosters hope and keeps them at ease. This aligns with the assertion of Hood et al. (2009) that "sacred objects not only provide comfort and solace but a sense of identity and cohesion. They also arouse religious and spiritual thoughts and feelings that calm, refresh, and strengthen distressed individuals" (p. 465).

Dungaw is an authentic form of Filipino Catholic popular piety. It is anchored upon the teachings of the Catholic Church, wherein "popular piety can refer to multiple and varied expressions of simple and fervent faith in God, of love for Christ the Redeemer, of invocations of the Holy Spirit, of devotion to the Blessed Virgin Mary, of the veneration of the Saints of commitment to conversion and fraternal charity" (Congregation for Divine Worship \& the Discipline of the Sacraments, 2001, para. 6). Also, it draws inspiration from Filipino Catholic culture, wherein sacred images were paraded to bless a town or protect people from calamities. More importantly, dungaw is an innovative way of communing with the Church. It is also an act that shows strong cognitions of the reality of God. In sharp contrast to some people who wondered about the reality of God and the purpose of religion in the face of real human suffering (Abellanosa, 2020), the Filipino Catholics who practiced dungaw claimed that they felt God's presence and benefitted from divine help.

Table 6 shows the implications of dungaw to the communal life of selected Filipino Catholics during the COVID-19 pandemic. The practice of dungaw helped some Filipino Catholics to be in communion with the Church. This communion refers to the "personal union of each human being with the divine Trinity and with the rest of mankind, initiated with the faith" (Congregation for the Doctrine of the Faith 1992, para. 3). To cope with the challenges brought by the COVID-19 pandemic, the selected Filipino Catholics utilized their religion and prayed. However, dungaw is not meant to be a private ritual. The sacred images are placed near the window or door so that other people will see it and be reminded to pray. Some of the respondents hope that people suffering from anxiety and stress will experience emotional relief after seeing the sacred images. Also, some respondents claimed that they were able to show concern for the well-being of their neighbors through dungaw since they cannot personally tell them to "take care."

Dungaw is also an embodiment of the traditional Filipino value called "pagdadamayan" or empathy and concern for others. Such Filipino value is deeply consonant with the Catholic vision and helps build a community (Catholic Church Bishops' Conference of the Philippines, 1997). Moreover, through dungaw, the selected Filipino Catholics were able to practice other traditional Filipino values of "pagkalinga" (to care for others) and "bayanihan" (a spirit of communal unity and cooperation) which are crucial in the fight against the COVID-19 pandemic. 


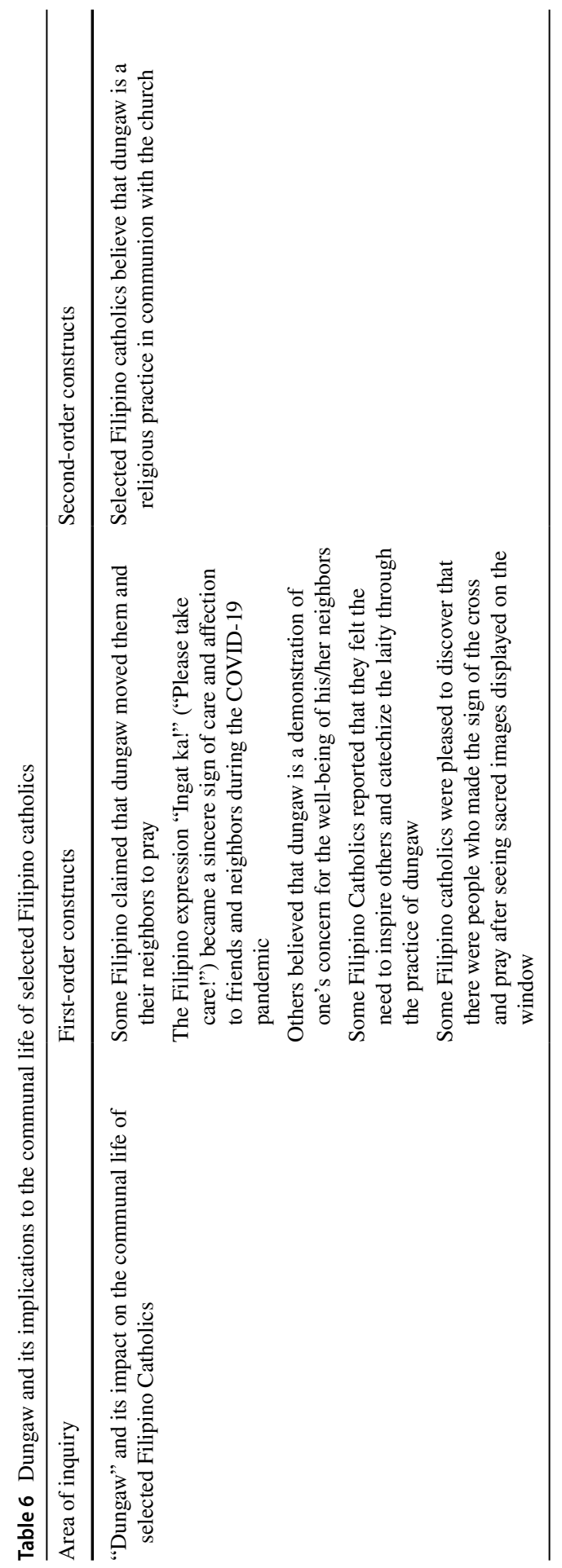




\section{Limitations and Strengths}

This study of a popular form of Catholic religiosity provides a critical look at the contribution of a re-imagined Catholic religious expression to the well-being of some Filipino Catholics during the COVID-19 pandemic. At the moment, there is a dearth of studies on popular forms of Catholic religiosity as a coping resource to deal with the global health crisis. Nevertheless, we are aware that we have a small number of respondents and that the study focused on the psychological state of selected Filipino Catholics. A study can be pursued by other researchers using a larger sample and investigate how religious piety supports the mental, physical, and spiritual health of people struggling with a major life stressor.

\section{Conclusion}

Regardless of time or place, religion is omnipresent and affects people's lives (Hood et al., 2009, p. 2). However, the importance of religion as a coping resource is highlighted during major trials of human existence such as the COVID-19 pandemic. In the Philippines, where most people profess the Catholic faith, the salience of religion, popular piety, and adaptive coping strategies were demonstrated in the practice of dungaw among selected Filipino Catholics. The COVID-19 significantly disrupted the lives of many Filipinos. The pandemic may also have contributed to the negative psychological states of some people. However, the popular form of religious piety, such as dungaw mediated feelings of joy and facilitated togetherness. Catholic prayers, which are integral to the practice of dungaw, fostered hope among selected Filipino Catholics. Believing that the transcendent has control over life-threatening situations, some Filipino Catholics felt good, optimistic, and less depressed.

To non-believers, statues of deities placed near the window or door of a house during the COVID-19 pandemic may seem unsophisticated and superstitious. However, for selected Filipino Catholics, dungaw is a genuine act of faith deeply rooted in Filipino culture. By collaborating with God, some Filipino Catholics were able to navigate the unchartered waters of COVID-19. The empirical phenomenology of dungaw revealed that popular piety and prayers help people feel God's presence. Despite being sheltered-in-place, dungaw connected the selected Filipino Catholics with other members of the Catholic Church. Also, some Filipino Catholics embraced dungaw as a "weapon against the pandemic." Since COVID-19 infects not just the body but can also harm the mind, dungaw and prayers helped foster a positive psychological state among selected Filipino Catholics. Indeed, religion served as a haven for distressed individuals. More importantly, dungaw contributed to the repair of the frayed social fabric when the selected Filipino Catholics practiced the traditional Filipino values of "pagdadamayan," "pagkalinga", and "bayanihan". 
Author Contributions FAC: Conceptualization, writing, review and editing; CDC: Writing, review and editing; JCC: Drafting and data collection.

Funding No funding was received for this paper. The authors declare that they have no known competing financial interests or personal relationships that could have appeared to influence the work reported in this paper.

\section{Declarations}

Conflict of interest The authors declare that they have no Conflict of interest.

\section{References}

Abellanosa, R. (2020). The church as a sacrament in a time of pandemic: The Philippine experience. Studies in World Christianity, 26(3), 261-280. https://doi.org/10.3366/swc.2020.0309

Aberth, J. (2005). Religious mentalities. In J. Aberth (Ed.), The black death.Palgrave Macmillan.

Abogado, J. (2006). The cult of saints among Filipino Catholics: A study of inculturation. Philippiniana Sacra, 123, 499-541

Alejo, A. (2004). 'Popular spirituality as cultural energy' lecture series 3 on spirituality: Context and expressions of Filipino spirituality. Center for Spirituality Manila.

Aspers, P. (2009). Empirical phenomenology: A qualitative research approach (the cologne seminars). Indo-Pacific Journal of Phenomenology, 9(2), 1-12. https://doi.org/10.1080/20797222.2009.11433 992

Baker, J., Martí, G., Braunstein, R., Whitehead, A. L., \& Yukich, G. (2020). Religion in the age of social distancing: How COVID-19 presents new directions for research. Sociology of Religion, 81(4), 357370. https://doi.org/10.1093/socrel/sraa039

Bautista, J. (2010). Figuring catholicism: An ethnohistory of the santoniño de cebu. Ateneo de Manila University Press.

Belavich, T. G. (1995). The role of religion in coping with daily hassles. Paper presented at the annual convention of the American Psychological Association.

Bramstedt, K. A. (2020). COVID-19 as a cause of death for Catholic priests in Italy: An ethical and occupational health crisis. Health and Social Care Chaplaincy, 8(2), 180-190. https://journals.equin oxpub.com/HSCC/article/view/41620

Buenaventura, Robert, Jacqueline, B. H., \& Lapid, M. I. (2020). COVID-19 and mental health of older adults in the Philippines: A perspective from a developing country. International Psychogeriatrics. https://doi.org/10.1017/S1041610220000757

Cameron, A. (2016). The cult of the virgin in late antiquity: Religious development and myth-making. Cambridge University Press.

Catholic Church Bishops' Conference of the Philippines. (1997). Catechism for Filipino Catholics. ECCCE Word and Life Publications.

Center for Strategic and International Studies. (2020). Southeast Asia Covid-19 Tracker. Retrieved December 4, 2020 from https://www.csis.org/programs/southeast-asia-program/southeast-asiacovid-19-tracker-0

Congregation for Divine Worship and the Discipline of the Sacraments. (2001). Directory on Popular Piety and the Liturgy. Retrieved December 1, 2020 from http://www.vatican.va/roman_curia/congr egations/ccdds/documents/rc_con_ccdds_doc_20020513_vers-direttorio_en.html

Congregation for the Doctrine of the Faith. (1992). Letter to the bishops of the Catholic Church on some aspects of the church understood as communion. Retrieved December 3, 2020 from http://www. vatican.va/roman_curia/congregations/cfaith/documents/rc_con_cfaith_doc_28051992_commu nionis-notio_en.html

Creswell, J. W. (1998). Qualitative inquiry and research design: Choosing among five traditions. Sage Publications. 
Deguma, J., Case-Deguma, M., \& Tandag, J. (2019). Popular religiosity: Experiencing Quiapo and Turumba. International Journal of Humanities and Social Science., 2, 1-11

Dein, S., Loewenthal, K., Lewis, C. A., \& Pargament, K. I. (2020). COVID-19, mental health, and religion: An agenda for future research. Mental Health Religion \& Culture, 23, 1-9

del Castillo, F.A., del Castillo, C. D., Aliño, M. A., Nob, R., Ackert, M., \& Ching, G. (2020). Validation of the interreligious forms of the centrality of religiosity scale (CRSi-7, CRSi-14, and CRSi-20): Salience of religion among selected youth in the Philippines. Religions, 11(12), 641. https://doi.org/ 10.3390/rel11120641

del Castillo, F.A., \& Alino, M. (2020). Religious coping of selected Filipino Catholic youth. Religions, 11,462

del Castillo, F. A. (2015). Christianization of the Philippines. Mission Studies, 32(1), 47-65

del Castillo, F.A. (2020). Health spirituality and Covid-19: Themes and insights. Journal of Public Health,185. https://doi.org/10.1093/pubmed/fdaa185

Espiritu, W. (2016). People's Mysticism and political engagement: The prophetic character of the nazareno image. Retrieved December 1, 2020 from https://www.academia.edu/32493183/Peoples_Mysti cism_and_Political_Engagement_The_Prophetic_Character_of_the_Nazareno_Image

Fauci, A. S., Lane, H. C., \& Redfield, R. R. (2020). Covid-19: Navigating the uncharted. The New England Journal of Medicine, 382(13), 1268-1269. https://doi.org/10.1056/NEJMe2002387

Goh, R. (2005). Christianity in Southeast Asia. ISEAS Publishing. https://doi.org/10.1355/9789812307 033

Hart, C., \& Koenig, H. (2020). Religion and health during the COVID-19 pandemic. Journal of Religion and Health, 59, 1141-1143. https://doi.org/10.1007/s10943-020-01042-3

Hood, R., Hill, P., \& Spilka, B. (2009). Psychology of religion. (4th ed.). Guilford Press.

Huber, S., \& Huber, O. (2012). The centrality of religiosity scale (CRS). Religions, 3, 710-724

James, W. (1917). The varieties of religious experience: A study in human nature. Being the Gifford Lectures on Natural Religion.

Jeppsen, B., Pössel, P., Black, S. W., Bjerg, A., \& Wooldridge, D. (2015). Closeness and control: Exploring the relationship between prayer and mental health. Counseling and Values, 60(2), 164-185. https://doi.org/10.1002/cvj.12012

John Paul II. (1984). Salvifici doloris. On the christian meaning of human suffering. Retrieved from http://www.vatican.va/content/john-paul-ii/en/apost_letters/1984/documents/hf_jp-ii_apl_11021 984_salvifici-doloris.html

John Paul II. (1981). Message of his holiness John Paul II to the president and the people of the Philippines. Retrieved December 1, 2020 from http:/www.vatican.va/content/john-paul-ii/en/speeches/ 1981/february/documents/hf_jp-ii_spe_19810217_manila-presidente.html

Kockelmans, J. J. (Ed.). (1967). Phenomenology. Doubleday.

Koenig, H. (2012). Religion, spirituality, and health: The research and clinical implications. ISRN Psychiatry, 2012 (278730), 1-34. https://doi.org/10.5402/2012/278730

McCullough, M. E., \& Larson, D. B. (1999). Prayer. In W. R. Miller (Ed.), Integrating spirituality into treatment: Resources for practitioners. (pp. 85-110). American Psychological Association.

Meier, M. (2016). The 'Justinianic Plague': The economic consequences of the pandemic in the eastern Roman empire and its cultural and religious effects. Early Medieval Europe, 24(3), 267-292. https:// doi.org/10.1111/emed.12152

Nakonz, J., \& Shik, A. (2009). And all your problems are gone: Religious coping strategies among Philippine migrant workers in Hong Kong. Mental Health Religion \& Culture, 12, 25-38

Ortiz, E., Faith, J. P., Relampagos, J. R., Pejana, S., Shene, M. B., Siarot, N. A., Tolo, S., Melchor, R. S., \& Inocian, R. B. (2017). The Transition of Sinulog dance festival in the face of modernization. International Journal of Research: Granthaalayah, 5(3), 293-309. https://doi.org/10.5281/zenodo. 478895

Pabillo, B. (2020). Pastoral statement: Consecration of the archdiocese to the blessed Virgin Mary. Retrieved from https://www.rcam.org/index.php/component/k2/item/792-pastoral-statement-conse cration-of-the-archdiocese-to-the-blessed-virgin-mary

Parks-Stamm, E., Pollack, J., \& Hill, D. (2019). The impact of prayer direction on emotional and cognitive responses to personal problems. Psychology of Religion and Spirituality. https://doi.org/10. $1037 /$ rel0000280

Patinio, F. (2020). More Pinoys believe faith 'very important' in fighting COVID-19. Philippine News Agency. Retrieved November 13, 2020 from https://www.pna.gov.ph/articles/1108913 
Pargament, K., Koenig, H., \& Perez, L. (2000). The many methods of religious coping: Development and initial validation of the RCOPE. Journal of Clinical Psychology, 56, 519-544

Pargament, K., Feuille, M., \& Burdzy, D. (2011). The brief RCOPE: Current psychometric status of a short measure of religious coping. Religions, 2, 51-76

Pargament, K. I., Kennell, J., Hathaway, W., Grevengoed, N., Newman, J., \& Jones, W. (1988). Religion and the problem-solving process: Three styles of coping. Journal for the Scientific Study of Religion, 27, 90-104

Peterson, W. (2020). Dancing, marching and baton twirling with the virgin: Performing community at the Peñafrancia festival in the Philippines. Australasian Drama Studies, 76, 24-61

Philippine Statistics Authority. (2017). Results from the 2015 Census of Population. Retrieved December 3, 2020 from https://psa.gov.ph/population-and-housing/node/120080

Rilveria, J. R. (2018). The development of the Filipino coping strategies scale. Asia-Pacific Social Science Review, 18, 111-126

Rosales, R. J. J. (2021). Online Eucharistic celebration and the spiritual well-being of the catholic faithful of san Isidro Labrador Parish, Cuenca, Batangas during COVID-19 pandemic. International Journal of Research Studies in Education, 10(1), 37-45. https://doi.org/10.5861/ijrse.2020.5920

Singh, D. E. (2020). Role of religions in the spread of COVID-19. Journal of Ecumenical Studies, 55(2), 289-310. https://doi.org/10.1353/ecu.2020.0019

Social Weather Stations. (2019). Fourth Quarter 2019 Social Weather Survey: Record-high 83\% of adult Filipinos say religion is "very important". Retrieved November 6, 2020 from https://www.sws.org. ph/swsmain/artcldisppage/?artcsyscode=ART-20200412155426

Strand, P. S. (2009). Religion as schedule-induced behavior. Behavior Analyst, 32, 191-204. https://doi. org/10.1007/BF03392183

Talik, E. (2013). The adolescent religious coping questionnaire. Translation and cultural adaptation of pargament's RCOPE scale for polish adolescents. Journal of Religion and Health, 52, 143-158

Vallejo, B., \& Ong, R. (2020). Policy responses and government science advice for the COVID 19 pandemic in the Philippines: January-April 2020. Progress in Disaster Science. https://doi.org/10. 1016/j.pdisas.2020.100115

Vizzi, D. (2020). Story of "Miraculous Crucifix, " where pope prayed for an end to coronavirus. Retrieved from https://www.romereports.com/en/2020/03/16/story-of-miraculous-crucifix-where-popeprayed-for-an-end-to-coronavirus/

World Health Organization. (2020a). Coronavirus disease (COVID-19) pandemic. Retrieved December 1, 2020 from https://www.who.int/emergencies/diseases/novel-coronavirus-2019

World Health Organization. (2020b). Coronavirus disease (COVID-19) advice for the public. Retrieved December 1, 2020 from https://www.who.int/emergencies/diseases/novel-coronavirus-2019/ advice-for-public

Publisher's Note Springer Nature remains neutral with regard to jurisdictional claims in published maps and institutional affiliations. 